\title{
TRACING NATIVE TEACHER TALK AND CLASSROOM INTERACTION IN EFL CONTEXT
}

\author{
Jihan Aisha Khirahla ${ }^{1}$ and Peptia Asrining Tyas ${ }^{2}$ \\ (aishakhirahla@hotmail.com) \\ ${ }^{1}$ Universitas Brawijaya \\ ${ }^{2}$ Universitas Brawijaya
}

\begin{tabular}{|c|c|}
\hline ARTICLE & ABSTRACT \\
\hline Keywords: & Since teacher talk is a necessary input for the students in an EFL (English as a \\
\hline Teacher talk, & $\begin{array}{l}\text { categories of teacher talk and the classroom interaction in young learners' } \\
\text { classroom at reputable English Courses in Malang. This study used descriptive }\end{array}$ \\
\hline Classroom & qualitative as the research design by using an observation sheets and an \\
\hline Interactions, & $\begin{array}{l}\text { interview guide as the instruments. Besides, the researcher recorded the audio } \\
\text { for every meeting. The result shows that, the teacher talk used in the classroom }\end{array}$ \\
\hline English for Young & $\begin{array}{l}\text { has been classified as direct teacher talk covering informing something, giving } \\
\text { directions, and justifying students' authority. For the classroom interaction in }\end{array}$ \\
\hline Learner & $\begin{array}{l}\text { the class, it was found that the way students responded to their teacher's talk } \\
\text { was by individually. Further, it was found that direct teacher talk was } \\
\text { implemented in the learning process and the implementations of this teacher } \\
\text { talk were also connected with the way the students respond to their teacher talk. }\end{array}$ \\
\hline
\end{tabular}

\section{INTRODUCTION}

Teacher talk is a necessary input for the students in an EFL (English as a Foreign Language) classroom (Nunan (1993); Nunan and Lamb (199); Gebhard (2000). Additionally, according to Putri (2015), teacher talk in the classroom plays an important role, and also has a very strong effect on student interaction in class. As teacher talk becomes undeniably an important feature in relation to classroom interaction, teachers should use simple diction whenever they want to give some instructions while teaching. What a teacher says in class must be easily understood and can be absorbed by students. As supported by Nurpahmi (2017), teacher talk must be clear as well as no mistakes. On the other hand, Students, especially young learners, may need a teacher who can understand them and also make the learning become fun and interesting. Supported by Pujiastuti (2013), young learners need various kinds of treatments to make the children-teacher relationship become more intimate. Thus, as EFL teachers, it is important to successfully deliver 
all the materials by preparing fun and interesting activity for their students so that the process of delivering the materials can be done very well.

Teacher talk is the language used and said by the teacher which is assigned to the students in the class. Teacher talk is closely related to classroom interaction. As stated by Heath (1978), "Teacher talk can be characterized as a 'caregiving' style which has certain identifiable phonological, lexical, and grammatical features." Thus, teachers must be able to focus on the attainment of the students materials in the class as well as manage the students by the use of language or as called as teacher talk (Astiti, N. 2012).

\section{TEACHER TALK CATEGORIES}

There are a lot of teacher talk categories from a lot of theories by some experts. According to Smith (1976), teacher talk could be as direct or indirect teacher talk. The categorization of each teacher's talk depends on the theory chosen. In this study, the researcher used teacher talk categories based on Celce-Murcia (1989), she differentiated teacher talk as indirect and direct teacher talk. For indirect teacher talk there are four kinds of fields as follows: (1) Offering the questions, the teacher presented some questions to students. For instance, after the teacher has announced the topic being discussed at the beginning of the lesson, the teacher asked "Okay, is there anything that you know about today's topic?" (2) Receiving the students' feelings, the teacher embraces what the students' feelings e.g. when students will have a test and the teacher probably asks his/her students about how their feelings are. The students may answer their teachers' question with nervousness and anxiety. When the teacher can accept and understand the conditions of his/her students, it is called as receiving the students' feelings. (3) Stimulate the students' motivation, an act of increasing the motivations from the students. Teachers may give students some interesting pre-activities, or use the terms playing while studying. By doing those, it may help the students to stay motivated in joining classroom activities. (4) Using the perceptions of the students, when deciding something, the teacher can use some leading questions for students to lead them giving some opinions and comments related to the activity, so that the students will feel happy and proud when the teacher uses his/her ideas.

On the other hand, direct teacher talk happens when the teacher: (1) Informing something, the teacher gives detailed information during the teaching-learning activities. For example, the teacher mentions the rules of the class, mentions one by one about the activities that are going to be conducted, gives explanations about the topic being discussed, and something like that. (2) Give the directions to the students: giving directions can make students become more controlled over 
everything. When the teacher can give direction well, the teacher will be able to manage the students as well. (3) Justifying or confirming the students' authority, the teacher gives students "power" to do or decide something. For instance, when the teacher asked students whether they finished their homework or not, the teacher then let the students who finished their homework to draw an extra star on the whiteboard.

\section{CLASSROOM INTERACTION}

Classroom is a place where students can learn and do something at school while interaction means the activity between students to teacher, teacher to students, as well as among students. Related to teacher talk, classroom interaction means something that happened between the teacher and also the students. As stated by Astuti (2011), classroom interaction is a process of two or more people involved together in declaring and accepting messages in the form of ideas, feelings or opinion that happened in the classroom. In addition, teachers and learners are having a bilateral outcome over each other through the way they talk and do (Murtiningrum (2009). Therefore, classroom interaction can be defined as the activities and communication happens between teacher and students in the classroom.

Teacher talk is closely related with the classroom interaction. As supported by Abhkaron (2013), classroom interaction's pattern is tied in with teacher talk and the process of development of thinking skills. Followed by the statement from Putri (2015), “Teacher talk highly has a deep impact on the classroom interaction that occurs on the classroom among students." Teacher talk may affect the students' response. Response is a backlash to the experiences, questions, or other type of encouragement (Response, n.d.). The way the students respond to their teacher depends on how the teacher delivers every aspect in the classroom. A good classroom interaction will happen if the students understand about what the teacher says. Thus, teachers must be able to manage their teacher talk properly in order to have a good classroom interaction.

The objectives of this study are to know whether the teacher tends to use indirect or direct teacher talk, to know how the classroom interaction occurs in the classroom, and to see teacher talk occurs in the classroom from students' point of view. The findings of this study were expected to help English teachers, especially the ones who teach young learners to be more concerned about their teacher talk and the way they interact in the classroom. Moreover, by knowing the perception of the students, it would be a reflection for the teacher to become better in teaching in the EFL classroom. 


\section{METHOD}

In this current study, the researcher analyzed the Teacher Talk and Classroom Interaction in High Flyer level at EF Sawojajar Malang. The researcher used descriptive qualitative as the research design. Qualitative research is closely related to the phenomena that happened in our surroundings. In this case, the research was conducted in classroom interaction through observing the teaching and learning process focusing on teachers' talk and classroom interaction.

The teacher that has been chosen as the subject of the research is an English native speaker from Australia. She is known as Miss "S". She is originally from Australia. The reason underlying the decision in choosing native speaker as the subject was because native English teacher will help the students better in learning and speaking in English. As supported by Masrizal (2013), "Native speakers, on the other hand, have a 'sense' which can assist them to detect whether the students use the right choice of words or not". Native teachers are able to gain better outcomes in communication (Madrid \& Canado, 2004). Thus, the researcher has decided Miss "S" as the subject of her research. In addition, there were 9 students enrolled in the classroom being observed. The students were in the age of 7-9 years old.

In conducting this research, the researcher used 2 kinds of instruments. The first instrument was adopted from Celce-Murcia (1989) comprising the categories of teacher talk. This instrument consists of 7 items. Three (3) items were used to get information about direct teacher talk while the others four (4) items were intended to find information about indirect teacher talk. The researcher used an observation sheet (see Table 1) to conduct the observation. The second instrument was an interview guide. The questions on this interview guide were adapted from Setiawati (2012). This instrument consists of ten (10) statements to know the students' perception towards their teacher talk as seen on Table 2.

Table 1. Observation Sheet

Observation Day（ ） Date : , 20

\begin{tabular}{|l|l|l|l|}
\hline \multicolumn{1}{|c|}{ Items } & Yes & No & Descriptions \\
\hline Informing Something & & & \\
\hline Giving Directions & & & \\
\hline Justifying students' authority & & & \\
\hline Accepting students' feeling & & & \\
\hline Stimulating students' motivation & & & \\
\hline
\end{tabular}




\begin{tabular}{|l|l|l|l|}
\hline Using students' feeling & & & \\
\hline Offering questions & & & \\
\hline
\end{tabular}

Adopted from Celce-Murcia (1989)

Table 2. Interview Guide

\begin{tabular}{|l|l|l|l|l|}
\hline No. & \multicolumn{1}{|c|}{ Items } & Yes & No & Note \\
\hline 1. & I like to listen to teachers' instructions. & & & \\
\hline 2. & $\begin{array}{l}\text { The teacher helps me to solve my problems in the } \\
\text { learning process. }\end{array}$ & & \\
\hline 3. & Teacher gives me a lot of praise. & & & \\
\hline 4. & $\begin{array}{l}\text { The teacher was usually mad at me when I didn't } \\
\text { obey her rules. }\end{array}$ & & & \\
\hline 5. & $\begin{array}{l}\text { Teacher gives me a lot of chances to talk and have } \\
\text { a discussion. }\end{array}$ & & & \\
\hline 6. & $\begin{array}{l}\text { Teacher pointed immediately when my answer } \\
\text { was incorrect. }\end{array}$ & & & \\
\hline 7. & I like the way the teacher teaches me. & & & \\
\hline 8. & $\begin{array}{l}\text { The teacher uses simple diction while giving } \\
\text { instruction. }\end{array}$ & & & \\
\hline 9. & I like to be asked and answered in the class. & & & \\
\hline 10. & I understand everything that the teacher says. & & & \\
\hline
\end{tabular}

Adopted from Setiawati (2012)

In analyzing the data, there were several steps done by the researcher. First, the researcher connected things that happened in the learning process with the categories of teacher talk on the observation sheet. After that, the data were analyzed from the transcribed audio from each meeting. Last, in analyzing the students' perception towards their teachers' talk, the researcher then described the results one by one descriptively on the findings and discussions sections.

In order to strengthen the results of the study, the researcher used the data source triangulation. Based on Denzim (1978) and Patton (1999) in Carter et al. (2014), data source triangulation is used when the research involved the collections of the data from different kinds of individuals, groups of people, communities, and families so that the results would have the different perspectives in order to prove the validity of the research. Thus, the researcher used 
JEASP

Journal of English for Academic and Specific Purposes

Volume 3 Number 1, June, 2020

triangulation to make sure if the result is trustworthy by collecting the data from the teacher as well as the students.

\section{FINDINGS AND DISCUSSION}

The finding and discussion will be elaborated in two sections as follows:

\section{Direct Teacher Talk and Classroom Interaction}

Based on the teacher talk categories used, the researcher found that teacher talk happened in the classroom and was categorized as direct teacher talk. As the first evidence which is informing something, the teacher was stating the rules before the class started. It is clear that when she reminded and stated about the rules, she wanted her students to obey those. Moreover, the teacher also informed us about the lesson in detail. The teacher explained not only about the name of the fruits or vegetables but also how to pronounce it correctly. The second evidence is that the teacher talks in giving direction. In every different activity in the class, the teacher always gave direction on how to do something before the class started. For instance, before the students did the games the teacher gave them directions first. She gave it one by one and it was quiet details. It can be seen as in example from transcriptions below:

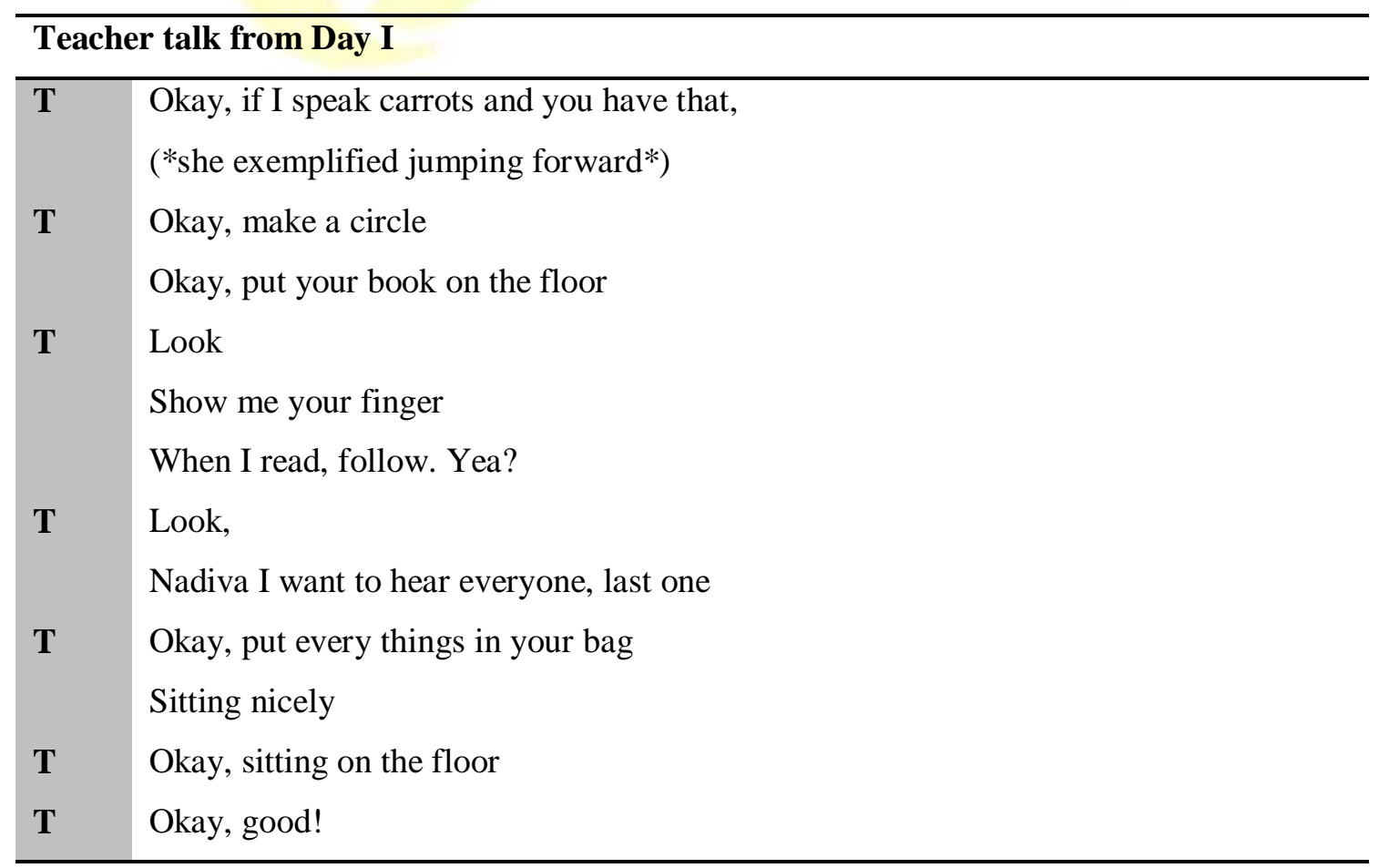


T Okay guys, time is up!

Please put your pencils back!

The last evidence of direct teacher talk is justifying students' authority in which the teacher gave the students their own "powers" to do something. On the first day for instance, when the students showed their homework to the teacher, the teacher then let the students draw an extra star by themselves on the whiteboard.

All in all, from the result of the observations, the types of teacher talk from Miss "S" were more leaded into the direct teacher talk compared to indirect ones. This direct teacher talk represents that the activities in the classroom were held friendly, cheerfully as well as enthusiastically. As supported by Cooper et al (2014), friendly, cheerful, sympathetic, morally virtuous, enthusiastic, and humorous are needed to be a good teacher. Further, as a teacher especially for those who teach young learners, classroom activities must be fun and interesting. As a result, it is a must for them to know how to teach, how to talk, and how to arrange the activities in the class. Thus, to be a good teacher they have to know everything related to the teaching process, how they arrange the activities in the classroom and it is also important for the teacher to have a good and pleasing personality.

In relation to classroom interaction, the result of the study found that the classroom interaction occurred on the class was good. The teacher plays an essential role in creating a great classroom interaction. The teacher and the students were working together to make the learning process successful. While conducting the class, the students were given a lot of directions and instructions as well. The way students responded to their teacher talk was individually. When the students were given the instructions, they directly did it well. They were not questioning or discussing with the other students when given the instructions. There were also a lot of activities that included speaking. Those activities made the students willing to talk and interact with each other. As stated by Sharliz (2017), when oral communication happens between each other in speaking class, classroom interaction actually occurs.

\section{Students' Perception on Their Teacher Talk}

Students' perception of their teacher talk is basically the way the students think of their teacher talk in the classroom. From the 10 statements given, most of the students agree with the statements except the statements number 9 which "I like to be asked and answer in the class". The 
aim of this question is to know whether the students are willing to be asked some questions and answer it. Three were six students who disagreed about that statement. It means that about $66 \%$ of the students do not like if the teacher gave them a question and they also did not like answering the questions. Graham \& Graham (2008) mentioned that there are several reasons that underlie students that make them won't answer the questions from the teacher, some of the reasons lean from the teacher and some of them lean from the students' itself. Further, another factor that might be underlying the students so they don't like being asked and answering questions is because they're afraid that the answers are wrong. Or the other possibility was because the students' lack of the significant background of the questions. Supported by Nye et al. (2009), students quickly examine that the questions from the teacher are boring if they lack the necessary background knowledge.

On the other hand, from the result of the interview, items number $1,2,3,4,5,6,7,8$, and 10 , it was found that the students and their teacher had a supportive relationship among each other. The teacher also seemed to be a good teacher for her students in the classroom since all of the students agreed that they like the way the teacher teaches them. All of them said that they can understand everything that the teacher says as well as the teachers' instruction because the teacher uses simple diction while giving the instruction. Additionally, students also said that although the teacher made them when they didn't obey her rules and pointed immediately when their answer was incorrect, the teacher helps them to solve their problems in the learning process and also gives them a lot of chances to talk and have a discussion. This finding is in line with Kutnick \& Jules (1993) who say that a good teacher was recognized for their relative qualities including the sense of understanding, forbearance, modesty, urge to participate with all the students, praise, and managing the behavior democratically. All in all, it can be said that in this current study, the students have a good perception of their teacher's talk because the teacher has succeeded in creating a good impression too.

\section{CONCLUSION}

In conclusion, based on the result from the interview, the result shows that the students and their teacher had a supportive relationship among each other. The teacher also seemed to be a good teacher for her students in the classroom. Hence, the students have a good perception of their teacher's talk because the teacher has succeeded in creating a good impression too. From this finding, it can be said that teacher talk occurs during classroom activities becomes an essential feature as well as has a very strong effect on student interaction in class. Thus, what a teacher says 
in class must be easily understood and can be absorbed by students. Additionally, in developing a good classroom interaction, teachers should use simple diction whenever they want to give some instructions while teaching and also give students various activities which are fun and interesting so that the material can be delivered well. Further, to broaden this current study, it is suggested for future researchers to conduct research about teacher talk in 2 different classes; one class with native English teacher and one with non-native speaker as the teacher. In addition, the future researcher can add the focus on the aspects of classroom management because the implementations of teacher talk must be different and the research can be more interesting and beneficial for English teachers.

\section{REFERENCES}

Abhkaron, J. (2013). Classroom interaction and thinking skills development through teacher talks. Kasetrart J. (soc.sci) 34, 116-125.

Astiti, N.W. (2012) An analysis of teacher talk in English classes in SMK PGRI 4 Denpasar. Jurnal Pendidikan dan Pembelajaran Bahasa Indonesia, 2(1). Retrieved from http://oldpasca.undiksha.ac.id

Astuti, M. (2011). An analysis of classroom interaction in the English teaching and learning process of the bilingual class in the first grade of SMPN 1 Prambanan. Thesis. Yogyakarta: Yogyakarta State University. Retrieved from http://eprints.uny.ac.id

Carter, N., Lokusius, D., Dicenso, A., Blythe, J., \& Neville, A. (2014). The use of triangulation in qualitative research. Oncology Nursing Forum. Vol 41(5).

Celce-Murcia, M. (1989). Interaction and communication in the ESOL classroom. In A Forum of Methodology (4).

Cooper, J., Irizarry, J., Leighton, M., Dershimer, G., Sadker, D., Sadker, M., Shostak, R., TenBrink, T., Tomlinson, C., Weber, W., Weinstein, C., \& Zittleman, K. (2014). Classroom teaching skills, tenth edition. Wandsworth, Cengage Learning.

Gebhard, J. G. (2000). Teaching English as a foreign or second language. USA: The University of Michigan Press

Graham, A., \& Graham, S. (2008). Getting students to answer questions.

Heath, S,B. (1978). Language in education: theory and practice. Teacher talk: language in the classroom. Arlington, Virginia : Center for Applied Linguistics.

Kutnick, P., \& Jules, V. (1993). Pupils' perceptions of a good teacher: a developmental perspective from Trinidad and Tobago. British Journal of Educational Psychology, 63, 400-413. 


\section{JEASP}

Journal of English for Academic and Specific Purposes

Volume 3 Number 1, June, 2020

Retrievedfrom

https://www.researchgate.net/publication/14905844_Pupils'_perceptions_of_a_good_teac her_A_developmental_perspective_from_Trinidad_and_Tobago

Madrid, D., \& Canado, L. (2004). Teacher and student preferences of native and nonnative foreign language teachers. Porta Linguarum 2.

Masrizal (2013). Native vs non-native English teachers. Jurnal ilmiah DIDAKTIKA, 13(2), 197211.

Murtiningrum, S. (2009). Classroom interaction in English learning. Thesis. Retrieved from httip://repository.usd.ac.id

Nunan, D. (1993). Understanding language classrooms. New York: Prentice Hall.

Nunan, D. \& Lamb, C.(1996). The self-directed teacher. Cambridge: Cambridge University Press.

Nurpahmi, S. (2017). Teacher talk in classroom interaction. ETERNAL, 3(1).

Nye, B., R.N., M.S. (2009). A summary of why don't students like school? A cognitive scientist answer questions about how the mind works and what it means for the classroom by Daniel Willingham summarized by Bud Nye, R.N., M.S.

Pujiastuti, R. (2013). An analysis of teacher talk and student talk in English for young learners (EYL). Journal of English and Education, 1, 163-172.

Putri, D. (2015). The analysis of teacher talk and the characteristic of classroom interaction in English as a foreign language classroom. Journal of English Education, 3(2), 16-27.

Setiawati, L. (2012). A descriptive study on the teacher talk at EYL classroom. Indonesian Journal of Applied Linguistics, 1, (2).

Sharliz, A. (2017). Classroom interaction in English speaking class : naturalistic study at queen English course karanganyar. Undergraduate Thesis. Retrieved from

Smith, E. C. (1976). A latitudinal study of pre-service instruction in flanders' interaction analysis categories. Doctoral dissertation. http://files.eric.ed.gov 